\title{
Fruit processing and the physiological quality of Euterpe edulis Martius seeds ${ }^{1}$
}

\author{
Patrícia Ribeiro Cursi²*, Silvio Moure Cicero ${ }^{3}$
}

\begin{abstract}
Different pulping methods were analyzed for Euterpe edulis, with regard to its seed physiological quality, and the physiological performance of seeds submitted to continuous drying and monitored by radiographs was assessed. In order to do so, $2 \times 2$ factorial design treatments were carried out, using two different manners to store fruit prior to pulping, immersed in water and not. Also, two different methods for the pulping of fruit were used for each lot; namely, manual and mechanical. Seeds from fruit that had been immersed in water at $40{ }^{\circ} \mathrm{C}$ for 20 minutes showed greater physiological performance than those that had not been immersed in water previously. Immersion in water at $55^{\circ} \mathrm{C}$ resulted in seed death. The pulp extraction method, whether manual or mechanical, did not affect seed physiological performance. Radiographs made it possible to observe that the volume occupied by embryos in the embryo cavity reduced with decreased water content. Mechanical pulping showed no reduction in percentage of seedling emergence for water content up to $33.3 \%$. However, reduction in water content to $16.1 \%$ caused seed death. The drying of manually pulped seeds until reaching $39.0 \%$ water content did not adversely affect seedling emergence, whereas lower water contents than $25.6 \%$ caused seed death.
\end{abstract}

Index terms: juçara palm, tolerance to drying, pulped fruit, $\mathrm{X}$ - ray.

\section{Métodos de despolpa e qualidade fisiológica de sementes de Euterpe edulis Martius}

\begin{abstract}
RESUMO - Foram estudados os efeitos de diferentes métodos de despolpa de frutos de Euterpe edulis sobre a qualidade fisiológica das sementes, e avaliado o desempenho fisiológico de sementes submetidas à secagem contínua assistida por tomada de imagens radiográficas. Para tanto, foram realizados tratamentos em arranjo fatorial $2 \times 2$, sendo duas formas de pré-condicionamento dos frutos, com e sem imersão em água, e dois métodos de despolpa, manual e mecânico, para cada lote. As sementes obtidas a partir de frutos imersos em água a $40{ }^{\circ} \mathrm{C}$ por 20 minutos apresentaram desempenho fisiológico superior. A temperatura da água a 55 ${ }^{\circ} \mathrm{C}$ para a imersão dos frutos foi prejudicial e ocasionou a morte das sementes. A forma de extração da polpa, não influenciou o desempenho fisiológico das sementes. As imagens de raios X possibilitaram observar a redução do volume ocupado na cavidade embrionária pelo embrião com a redução do teor de água. Para despolpa mecânica, não há redução na percentagem de emergência de plântulas para teor de água de até $33,3 \%$ e para 16,1\% de água a desidratação é letal. A secagem das sementes, despolpadas manualmente, até 39,0\% de água não prejudica a emergência de plântulas e a 25,6\% é letal.
\end{abstract}

Termos para indexação: palmiteiro juçara, tolerância à secagem, despolpa, raios - X.

\section{Introduction}

Euterpe edulis Martius, popularly known as "juçara palm", is a native tree of the Atlantic Rainforest of Brazil that has great ecological and socioeconomic importance.

Palms of the genus Euterpe are the most commonly grown for the production of hearts of palm and the great market demand has resulted in its disorderly exploitation, adding it to the list of Brazilian endangered flora species.

${ }^{1}$ Submitted on 06/04/2013. Accepted for publication on 04/10/2014.

${ }^{2}$ Coordenadoria de Assistência Técnica Integral - CATI, Caixa Postal 962, 13070-172 - Campinas, SP, Brasil.
The agribusiness of hearts of palm has significantly grown over the years and, according to the latest survey on the production of plant extraction and forestry, there has been a $13.1 \%$ increase in production, totaling 5563 tonnes of cultivated hearts of palm (IBGE, 2011).

The Euterpe edulis hearts of palm is one of the most exploited non-timber forest products of the Atlantic Forest (Fantini and Guries, 2007). Aiming at decreasing the predatory process, nonprofit organizations and government

${ }^{3}$ Departamento de Produção Vegetal, USP/ESALQ, Caixa Postal, 9, 13418-900 Piracicaba, SP, Brasil.

*Corresponding author < patrícia.cursi@cati.sp.gov.br> 
agencies have encouraged other options for the sustainable exploitation of this species, and the marketing of its fruit pulp to be used in human consumption has great potential for that (Cembraneli et al., 2009).

The production of native forest seed currently grows due to the increased demand for seedlings to be used in the recovery of degraded areas and the preservation of protected natural reserves (Smith et al., 2007). Especially in the state of São Paulo, a large number of companies from the agribusiness industry have undertaken reforestation projects in order to obtain environmental certification and access to financial subsidies (Brancalion et al., 2011). Thus, residues from the Euterpe edulis fruit agribusiness processing to extract pulp are "clean" seeds, with no epicarp nor mesocarp, which can be traded for the production of seedlings in nurseries for native forest species.

Considering that this species can only propagate through seed dispersal, the production of good quality seeds - taking into account their genetic, physical, physiological, and hygienic aspects - is critical to ensuring healthy and vigorous seedlings for the success of reforestation, enrichment of native woodlands and commercial crops.

E. edulis seeds are round and may range from 8 to 15 $\mathrm{mm}$ in diameter (Fleig and Rigo, 1998; Pizo et al., 2006; Martins et al., 2009b) and from 0.35 to 1.81 grams of dry matter (Brancalion et al., 2011). When freshly harvested, seeds have high water content (Brancalion et al., 2011; Roberto et al., 2011) and as shown by research studies on their storage conditions, are recalcitrant due to their sensitivity to dehydration and short life period when stored (Bovi and Cardoso, 1978; Queiroz and Cavalcante, 1986; Reis et al., 1999; Martins et al., 2000; Andrade, 2001). The very small embryo accounts for only $0.54 \%$ of the total seed mass and it has only a single prominent cotyledon, a short hypocotyl-radicle axis and epicotyl, storing protein and lipid substances as sources of reserve (Panza et al., 2004).

As with most palms, germination of E. edulis is unbalanced and slow (Bovi and Cardoso, 1976; Panza et al., 2004; Roberto and Habermann, 2010; Roberto et al., 2011), and may take from 60 to 90 days, not because the embryo is undeveloped, but because of a physical impediment that hinders the penetration of water (Bovi and Cardoso, 1976). Their thick mesocarp and hard endocarp could act as a barrier to seed imbibition, causing dormancy (Roberto et al., 2011).

The sowing of the whole fruit, if compared to that of shelled seed, presents lower germination values and increased mean time to germinate (Bovi and Cardoso, 1976). The pulping of fruits was favorable when considering germination speed and uniformity (Bovi et al., 1987). The pulping of fruit, which consisted of soaking it in water for three to four days, caused a stimulating effect of the pre-soaking treatment on the final percentage and speed of germination (Bovi, 1990). Furthermore, Martins et al. (2004) found that storing the whole fruit was unfavorable to the physiological quality of seed compared with storing pulped seeds.

Thus, the potential of having seed production combined with the production of pulp becomes a great technical, economic, and environmental move.

Given the above, this study aimed to assess how different methods of pulping Euterpe edulis fruit may affect the physiological performance of seeds and its tolerance to drying seeds, accompanied by radiographic images.

\section{Material and Methods}

Ripe fruits of Euterpe edulis were collected manually at two locations and in two different moments, forming two lots. Lot 01 was collected on December 1, 2011 from mother plants located in Parque das Neblinas, in the city of Mogi das Cruzes (Lat 23 44' 52" S, Log 46 $09^{\circ}$ '44” W); and Lot 02 was collected on May $24^{\text {th }}, 2012$ from mother plants near by the Experimental Station of the Agronomic Institute of Campinas, in the city of Ubatuba (Lat $23^{\circ} 24^{\prime} 38^{\prime}$ S, Log $45^{\circ}$ 06' 59" W). Both lots were transported to Piracicaba, SP, and stored in a cold chamber at $10{ }^{\circ} \mathrm{C}$ until the start of treatment, for a period of 24 hours.

Initially, ripe fruit was selected, cleaned and washed in tap water. Then it was sanitized in a 200 ppm solution of crop sanitizer (Sumaveg®) for 15 minutes.

After that, treatments were performed as follows: Treatment 1 (T1) - fruits were immersed in water and mechanically pulped; Treatment 2 (T2) - fruits were not immersed in water and were mechanically pulped; Treatment 3 (T3) - fruits were immersed in water and manually pulped; Treatment 4 (T4) - fruits were not immersed in water and were manually pulped.

For lot 01 , immersion in water at $40 \pm 2{ }^{\circ} \mathrm{C}$ was conducted for $20 \mathrm{~min}$, and this temperature was strictly kept under control and it was found to be the most appropriate in previous trials. For Lot 02 , the immersion temperature used was $55{ }^{\circ} \mathrm{C}$, for a period of 20 minutes, to simulate a less strict control with respect to temperature, considering the reality of the locations where fruit processing is made, such as traditional communities and rural populations. It was not possible to conduct any of these two treatments for neither lot due to the limited availability of seeds.

Pulp from processing was discarded and the seeds placed in plastic trays and kept in lab environment to remove excess 
water from the processing of fruit, for 24 hours.

Seed initial water content was determined in the oven at $105 \pm 3{ }^{\circ} \mathrm{C}$ for $24 \mathrm{~h}$ (Brasil, 2009).

A seedling emergence test was conducted to assess its physiological performance. A sterilized vermiculite moistened with water content equivalent to $60 \%$ of its water holding capacity was used as substrate. The test was conducted in a location with no control of temperature and relative humidity. The substrate was moistened and normal seedlings were weekly counted up until 90 days, in accordance with the Rules for Seed Testing (Brasil, 2009); and the final count was made at 135 days, period for which seedling emergence should stabilize.

Tests for the first count of seedling emergence, speed of seedling emergence, shoot length and dry weight of seedling, were performed simultaneously to the emergency test.

Seedling emergence was first counted when at least one treatment showed $10 \%$ of normal seedlings emerged. Seedling emergence speed was calculated based on the count of normal seedlings, every seven days for each replication, by applying the equation described by Maguire (1962). At the end of the emergency test, normal seedlings were removed from the substrate and shoot length was measured and expressed in $\mathrm{mm}$. Once that had been determined, normal seedlings, separated from the rest of the seed, were stored in paper bags and placed in an oven at $70{ }^{\circ} \mathrm{C}$ for 48 hours prior to weighing. The dry weight of seedlings was expressed in grams.

Aiming to assess tolerance to drying and the evolution of damage caused by it, seeds from treatment 1 , considered to be the recommended treatment for obtaining pulp, as well as seeds from treatment 4 , in this work assessed as control treatment, were subjected to continuous drying in an oven with air circulation at temperature of $30 \pm 2{ }^{\circ} \mathrm{C}$ at intervals of approximately $3 \%$ from initial water content, until exhaustion of available seed. For each water content, determined through the oven method at $105{ }^{\circ} \mathrm{C}$ (Brasil, 2009), the seeds were radiographed by a MX -20 Faxitron X-ray digital equipment, coupled to a Core 2 Duo computer $(3.16 \mathrm{GHz}, 2$ GB RAM and 160 GB Hard Disk) with a MultiSync LCD 1990SX 17-inch monitor. Seeds were distributed in plastic sheets and numbered according to their position, allowing for their identification to carry out subsequent measurements.

The experimental design was completely randomized with five replicates of 20 seeds. The analysis of variance for the pulping factors was conducted separately for each test, in a $2 \times 2$ factorial arrangement (manual and mechanical pulping, with and without prior immersion in water). Treatment mean comparison was made using Tukey's test at 5\% probability, with the aid of a 9.1 SAS software. Seedling emergence first count data were transformed into $\log (\mathrm{x}+1)$, for not having normal distribution.

For tolerance to drying, the experimental design used for all water contents obtained was the completely randomized type; and mean comparison for each water content was conducted using the Tukey test at $5 \%$ probability, with the aid of a 9.1 SAS statistical software.

\section{Results and Discussion}

\section{Pulping Methods}

Table 1 shows seed physiological performance for each pulping method. Seed initial water content ranged from $43.0 \%$ to $45.0 \%$ for Lot 01 and from $45.9 \%$ to $46.7 \%$ for Lot 02 , between treatments.

Mechanical impact caused by pulp extractor did not cause damage to the embryo. No significant differences were found between the manual and mechanical pulping methods used for the two lots analyzed (Table 1). The process of mechanical pulping to remove parts of the fruit had already been recommended to other genera of family Arecaceae (Ferreira and Gentil, 2006; Costa and Marchi, 2008) with the intent to accelerate and standardize the germination process.

Regardless of the pulping method, whether manual or mechanical, seeds from treatments that included fruit immersed in water at $40{ }^{\circ} \mathrm{C}$ for 20 minutes showed greater physiological performance, according to results found for Lot 01 . These treatments resulted in an increase of $19 \%$ and $14 \%$ in the percentage of seedling emergence, in each type of pulping, mechanical and manual, respectively, at 90 days after test application (Table 1). As for the final count, made at 135 days, an increase of $8 \%$ was noted for the mechanical pulping and $5 \%$ for manual pulping. Similarly, differences found in speed of seedling emergence at 90 days were greater than at 135 days. Thus, although there is an increase in the percentage of seedling emergence at 135 days, the 90 -day assessment was enough to show differences in the physiological performance of treatments, confirming the assessment time period recommended by the Rules for Seed Testing (Brasil, 2009).

Moreover, for the first count of seedling emergence, at 39 days after the application of test, a difference of up to $16 \%$ was noted for treatments with and without prior seed immersion in Lot 01 . Thus, differences in vigor for each treatment were more obvious at the beginning of tests, up to 90 days, and reduced over time.

The slow germination of the seeds of this palm is due to a physical impairment that hinders the penetration of water (Bovi and Cardoso, 1976; Roberto et al., 2011). When ripe, the fruit of the palm has a fully formed seed, ready to start 
the seed germination process. The embryo, although small, is fully developed. The only two impediments to germination are fruit pulp and the presence of a serous operculum that hinders the penetration of water in the seed (Bovi, 1990).

Table 1. Results obtained for water content (WC), seedling emergence at 90 days (E 1) and at 135 days (E 2), emergence speed rate at 90 days (ESR 1) and at 135 days (ESR 2), first count of seedling emergence (FC), shoot length of seedling (SL), and dry mass of seedling (DM) for pulping treatments applied to Euterpe edulis fruit.

\begin{tabular}{|c|c|c|c|c|c|c|c|}
\hline \multirow[b]{2}{*}{ Parameter } & \multirow[b]{2}{*}{ Pulping } & \multicolumn{2}{|c|}{ Lot 01} & \multirow{2}{*}{$\begin{array}{l}\text { CV } \\
(\%)\end{array}$} & \multicolumn{2}{|c|}{ Lot 02} & \multirow{2}{*}{$\begin{array}{l}\mathrm{CV} \\
(\%)\end{array}$} \\
\hline & & $\begin{array}{l}\text { With Immersion } \\
\left(40^{\circ} \mathrm{C} / 20^{\prime}\right)\end{array}$ & Without Immersion & & $\begin{array}{l}\text { With Immersion } \\
\left(55^{\circ} \mathrm{C} / 20^{\prime}\right)\end{array}$ & $\begin{array}{l}\text { Without } \\
\text { Immersion }\end{array}$ & \\
\hline \multirow{2}{*}{ WC (\%) } & Mechanical & 44.6 & 45.0 & - & 46.2 & 46.7 & - \\
\hline & Manual & 43.0 & 45.0 & - & 46.5 & 45.9 & - \\
\hline \multirow{2}{*}{ E $1(\%)$} & Mechanical & $91 \mathrm{aA}^{1}$ & $72 \mathrm{aB}$ & \multirow{2}{*}{8.53} & $0 \mathrm{aA}^{1}$ & $72 \mathrm{aB}$ & \multirow{2}{*}{31.27} \\
\hline & Manual & $86 \mathrm{aA}$ & $72 \mathrm{aB}$ & & $0 \mathrm{aA}$ & $71 \mathrm{aB}$ & \\
\hline \multirow{2}{*}{ E $2(\%)$} & Mechanical & $96 \mathrm{aA}$ & $88 \mathrm{aB}$ & \multirow{2}{*}{6.26} & $0 \mathrm{aA}$ & $82 \mathrm{aB}$ & \multirow{2}{*}{18.48} \\
\hline & Manual & $96 \mathrm{aA}$ & $91 \mathrm{aB}$ & & $0 \mathrm{aA}$ & $72 \mathrm{aB}$ & \\
\hline \multirow{2}{*}{ ESR 1} & Mechanical & $1.658 \mathrm{aA}$ & $1.100 \mathrm{aB}$ & \multirow{2}{*}{13.76} & $0 \mathrm{aA}$ & $1.04 \mathrm{aB}$ & \multirow{2}{*}{26.88} \\
\hline & Manual & $1.476 \mathrm{aA}$ & $1.146 \mathrm{aB}$ & & $0 \mathrm{aA}$ & $0.95 \mathrm{aB}$ & \\
\hline \multirow{2}{*}{ ESR 2} & Mechanical & $1.700 \mathrm{aA}$ & $1.214 \mathrm{aB}$ & \multirow{2}{*}{11.18} & $0 \mathrm{aA}$ & $1.125 \mathrm{aB}$ & \multirow{2}{*}{23.79} \\
\hline & Manual & $1.560 \mathrm{aA}$ & $1.300 \mathrm{aB}$ & & $0 \mathrm{aA}$ & $1.906 \mathrm{aB}$ & \\
\hline \multirow{2}{*}{ FC $(\%)$} & Mechanical & $18 \mathrm{aA}^{2}$ & $2 \mathrm{aB}^{2}$ & \multirow{2}{*}{99.07} & $0 \mathrm{aA}^{2}$ & $10 \mathrm{aB}^{2}$ & \multirow{2}{*}{103.93} \\
\hline & Manual & $8 \mathrm{aA}^{2}$ & $1 \mathrm{aB}^{2}$ & & $0 \mathrm{aA}^{2}$ & $5 \mathrm{aB}^{2}$ & \\
\hline \multirow{2}{*}{$\mathrm{SL}(\mathrm{mm})$} & Mechanical & $20.06 \mathrm{aA}$ & $17.12 \mathrm{aB}$ & \multirow{2}{*}{7.34} & $0 \mathrm{aA}$ & $14.67 \mathrm{aB}$ & \multirow{2}{*}{9.36} \\
\hline & Manual & $19.70 \mathrm{aA}$ & $17.27 \mathrm{aB}$ & & $0 \mathrm{aA}$ & $14.75 \mathrm{aB}$ & \\
\hline \multirow{2}{*}{$\mathrm{DM}(\mathrm{g})$} & Mechanical & $3.21 \mathrm{aA}$ & $2.60 \mathrm{aB}$ & \multirow{2}{*}{10.16} & $0 \mathrm{aA}$ & $2.01 \mathrm{aB}$ & \multirow{2}{*}{21.07} \\
\hline & Manual & $3.19 \mathrm{aA}$ & $2.60 \mathrm{aB}$ & & $0 \mathrm{aA}$ & $1.77 \mathrm{aB}$ & \\
\hline
\end{tabular}

${ }^{1}$ For each examined characteristic, means followed by the same lower case letter in the column and capital on the line do not differ statistically among themselves by Tukey test at $5 \%$ probability.

${ }^{2}$ The figures are the original data. For statistical analysis, the values were transformed into $\log (\mathrm{x}+1)$, for not having normal distribution.

Removing or simple perforating the operculum in palm seeds has proven to be efficient, as it increases the percentage of germinated seeds, according to Myint et al. (2010) and Goudel et al. (2013). Bovi and Cardoso (1976) have found for E. edulis that a slight scarification in the germ pore causes increased germination. In that same study, they observed that fruit immersed in water at room temperature, for a period of three days, and which had their pulp removed manually, had seeds with higher performance than those that were not pulped. Similar results were found by Bovi et al. (1987) for E. oleracea and E. edulis, where pulped fruit showed improvement in the speed and uniformity of germination. Increased germination speed rate for seeds of forest species represents an advantage, because it proves the important relationship of germination ability with the establishment of seedling in natural environment (Gomes et al., 2006; Brancalion and Marcos- Filho, 2008).

Treatments that included prior fruit immersion in water at $40{ }^{\circ} \mathrm{C}$ for $20 \mathrm{~min}$, showed differences of 2.94 and $2.43 \mathrm{~cm}$ for shoot length, and 0.61 and $0.59 \mathrm{~g}$ for seedling dry matter, for each type of pulping, mechanical and manual, respectively, demonstrating the beneficial effects that immersion has provided to seeds from Lot 01 (Table 1).

When assessing the consequences of pre-imbibition at room temperature for a period of three days, Bovi (1990) observed detrimental effects on fruit due to the presence of pathogenic microorganisms easily developed in high pulp humidity, affecting the seed. After fruit pre-imbibition, pulp was removed and "clean" seeds, exclusively, were sown with the intent to obtain better results. Similarly, two-day preimbibition of seeds clear of oleaginous pulp has positively affected the final germination percentage.

Thus, fruit immersion in water, in addition to improving both manual and mechanical extraction of pulp, it has probably eased the protrusion of plant bud. Immersion temperature of $40{ }^{\circ} \mathrm{C}$ may have decreased operculum mechanical strength, caused by changes in the physical properties of its serous layer.

As for seeds from fruit immersed in water at $55{ }^{\circ} \mathrm{C}$ for 20 minutes, immersion was not favorable to physiological performance, and this temperature has proven to be lethal for this species. Seeds from the same lot, which were not subjected to immersion, had greater performance than the 
immersed seeds, for all parameters studied.

Costa and Marchi (2008) have proposed that seed hydration at high temperatures can positively affected palm seed germination. The immersion of seeds from species of genera Acrocomia e Astrocaryum in a water bath at 65 and $70{ }^{\circ} \mathrm{C}$, for 2-3 weeks, was favorable for germination.

Wolkers et al. (1998) have reported that protein denaturation temperature is directly related to tolerance to seed drying. Studies on Arabdopsis thaliana, showed that for wild species, tolerant to drying, proteins did not denature when subjected to $150{ }^{\circ} \mathrm{C}$. As for mutants sensitive to water loss, there has been reduced temperature of protein denaturation for values from 68 to $87^{\circ} \mathrm{C}$.

Considering that Euterpe edulis seeds are highly sensitive to water loss, it is possible to assume that the temperature of $55^{\circ} \mathrm{C}$, used for the fruit, may have caused the denaturation of proteins that are essential for germination, which justifies the death of seeds in that treatment.

\section{Tolerance to drying}

The evolution of the drying process made it possible to monitor the reduction of the volume occupied by the embryo within the embryo cavity (Figure 1); thus, the embryo has been associated with the physiological performance of seeds (Tables 2, 3 and 4). When mapping images to test results, it was possible to note that treatments with the largest number of embryos occupying all or most of the embryo cavity have matched the ones that showed better physiological performance. Reduced water content resulted in decreased volume of embryo, appearance of void spaces, and increased percentage of dead seeds for treatments 01 and 04 in Lot 01 , and for treatment 04 in Lot 02 (Figure 1).
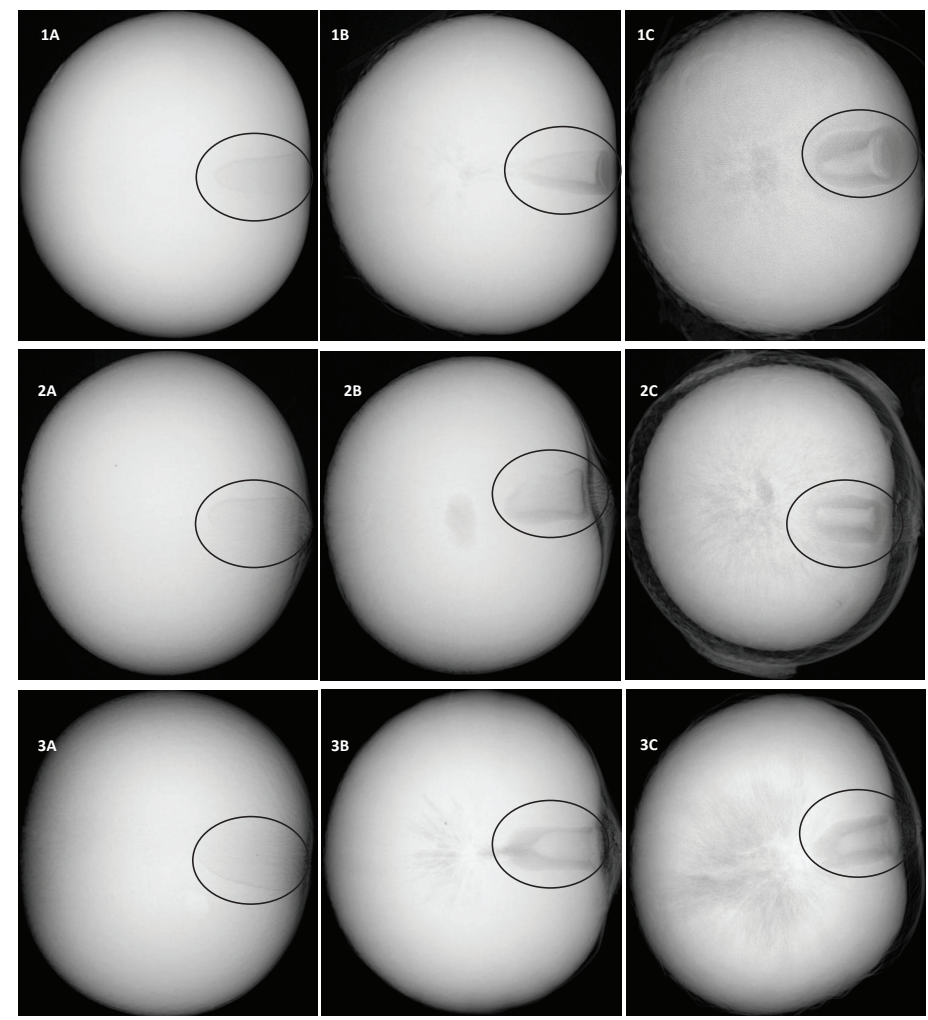

Figure 1. Representative image of the reduction of the volume occupied by the embryo within the embryo cavity throughout the drying process. 1 - Radiographic images that refer to treatment 01 , Lot 01 . 1A - initial water content of 44.9\%; 1B critical water content of $33.3 \%$; $1 \mathrm{C}$ - lethal water content of $16.1 \% .2$ - Radiographic images that refer to treatment 04 , Lot $01.2 \mathrm{~A}$ - initial water content of $44.9 \%$; $2 \mathrm{~B}$ - critical water content of $39.0 \% ; 2 \mathrm{C}$ - lethal water content of $20.4 \%$. 3 - Radiographic images that refer to treatment 04 , Lot $02.3 \mathrm{~A}$ - initial water content of $45.9 \%$; $3 \mathrm{~B}$ - critical water content of $37.0 \%$; $3 \mathrm{C}$ - lethal water content of $27.1 \%$. Embryo is highlighted.

For treatment 01 of Lot 02 , in which fruit were immersed in water at $55^{\circ} \mathrm{C}$ for 20 minutes, it was observed that even for initial water contents, embryos did not occupy the whole embryo cavity, and presented reduced volume compared with other treatments, yielding dead seeds for all water contents assessed (Figure 2). Protein denaturation caused by high temperature may 
have caused the disorganization and breakdown of membranes, resulting in the death of the embryo, detected by tests that assessed the physiological performance of different methods of pulping (Table 1) and shown in radiographs (Figure 2).
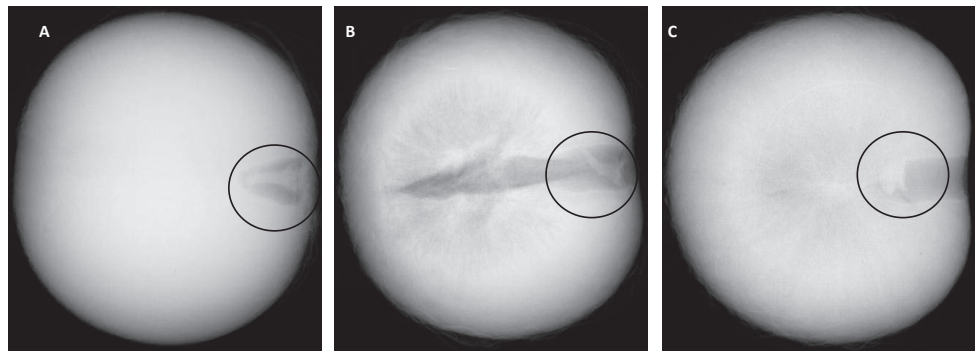

Figure 2. Representative image of the reduction of the volume occupied by the embryo within the embryo cavity during the drying process for treatment 01 of Lot 02 (in water at $55^{\circ} \mathrm{C}$ for 20 minutes), which yielded dead seeds. A - initial water content of $46.2 \%$; B - intermediate water content of $27.8 \%$; $\mathrm{C}$ - water content at the end of the drying process $13.6 \%$. Embryo is highlighted.

The progressive dehydration of seeds intensified the process of deterioration, evidenced by the reduction of all parameters for all treatments (Tables 2, 3 and 4), except for treatment 01 of Lot 02 , which performance was canceled due to the high immersion temperature used.

For Lot 01 , there has been a significant reduction in the percentage of seedling emergence at 90 days from water contents $33.3 \%$ and $39.0 \%$; and at 135 days for water contents $33.3 \%$ and $35.3 \%$ in treatments 01 e 04 (Tables 2 and 3), respectively. The emergence of seedlings was nulled for treatment 01 , when water content decreased to $16.1 \%$ (Table 2); and for treatment 04 , when water content reached

\section{$20.4 \%$ (Table 3 ).}

Regarding the speed of seedling emergence, a significant reduction to $35.7 \%$ and $39.0 \%$ for treatments 01 and 04 has occurred, respectively (Tables 2 and 3), as well as for seedling dry mass. The first count of seedling emergence for treatment 01 showed significant difference of $42.7 \%$ compared with initial water content (Table 2), and this was the test that showed the greatest sensitiveness to water loss. No seedling emergence was noted on the first count at 39 days for treatment 04 (Table 3). A reduction in shoot length of seedlings was noted with water content from $18.6 \%$ for treatment 01 (Table 2) and $22.4 \%$ for treatment 04 (Table 3).

Table 2. Results obtained for drying seeds from Lot 01, Treatment 01 - seedling emergence and emergence speed rate (ESR) at 90 and 135 days, first count of seedling emergence (FC), shoot length of seedling (SL) and dry mass of seedling (DM).

\begin{tabular}{|c|c|c|c|c|c|c|c|c|}
\hline \multirow{2}{*}{ Т 01} & \multirow{2}{*}{$\begin{array}{c}\text { Water } \\
\text { Content (\%) }\end{array}$} & \multicolumn{2}{|c|}{ Emergence (\%) } & \multicolumn{2}{|c|}{ ESR } & \multirow{2}{*}{$\begin{array}{l}\mathrm{FC} \\
(\%)\end{array}$} & \multirow{2}{*}{$\begin{array}{c}\mathrm{SL} \\
(\mathrm{cm})\end{array}$} & \multirow{2}{*}{$\begin{array}{c}\text { DM } \\
(\mathrm{g})\end{array}$} \\
\hline & & 90 days & 135 days & 90 days & 135 days & & & \\
\hline U0 & 44.9 & $80 a b^{1}$ & $87 \mathrm{ab}$ & $1.388 \mathrm{a}$ & $1.452 \mathrm{a}$ & $7 \mathrm{a}$ & $18.70 \mathrm{a}$ & $2.67 \mathrm{ab}$ \\
\hline U1 & 42.7 & $88 \mathrm{a}$ & $95 \mathrm{a}$ & $1.495 \mathrm{a}$ & $1.555 \mathrm{a}$ & $2 b$ & $20.08 \mathrm{a}$ & $3.07 \mathrm{a}$ \\
\hline $\mathrm{U} 2$ & 39.6 & $87 \mathrm{a}$ & $94 \mathrm{a}$ & $1.385 \mathrm{a}$ & $1.456 \mathrm{a}$ & $2 \mathrm{~b}$ & $20.47 \mathrm{a}$ & $2.68 \mathrm{ab}$ \\
\hline U3 & 35.7 & $76 a b$ & $83 \mathrm{ab}$ & $1.110 \mathrm{~b}$ & $1.216 \mathrm{~b}$ & $0 \mathrm{~b}$ & $18.56 \mathrm{a}$ & $2.39 \mathrm{bc}$ \\
\hline $\mathrm{U} 4$ & 33.3 & $71 \mathrm{~b}$ & $75 \mathrm{bc}$ & $0.908 \mathrm{~b}$ & $1.034 \mathrm{bc}$ & $0 \mathrm{~b}$ & $18.30 \mathrm{a}$ & $1.77 \mathrm{~cd}$ \\
\hline U5 & 29.8 & $55 \mathrm{c}$ & $67 \mathrm{c}$ & $0.639 \mathrm{c}$ & $0.858 \mathrm{c}$ & $0 \mathrm{~b}$ & $18.25 \mathrm{a}$ & $1.87 \mathrm{~cd}$ \\
\hline U6 & 27.0 & $45 \mathrm{c}$ & $46 \mathrm{~d}$ & $0.549 \mathrm{c}$ & $0.631 \mathrm{~d}$ & $0 \mathrm{~b}$ & $19.14 \mathrm{a}$ & $1.29 \mathrm{~d}$ \\
\hline U7 & 23.2 & $16 \mathrm{~d}$ & $16 \mathrm{e}$ & $0.209 \mathrm{~d}$ & $0.224 \mathrm{e}$ & $0 \mathrm{~b}$ & $17.78 \mathrm{ab}$ & $0.48 \mathrm{e}$ \\
\hline U8 & 18.6 & $4 \mathrm{de}$ & 5 ef & $0.044 \mathrm{~d}$ & $0.047 \mathrm{ef}$ & $0 \mathrm{~b}$ & $9.5 \mathrm{~b}$ & $0.13 \mathrm{e}$ \\
\hline U9 & 16.1 & $0 \mathrm{e}$ & $0 \mathrm{f}$ & $0.000 \mathrm{~d}$ & $0.000 \mathrm{f}$ & $0 \mathrm{~b}$ & $0.00 \mathrm{c}$ & $0.00 \mathrm{e}$ \\
\hline U10 & 15.2 & $0 \mathrm{e}$ & $0 \mathrm{f}$ & $0.000 \mathrm{~d}$ & $0.000 \mathrm{f}$ & $0 \mathrm{~b}$ & $0.00 \mathrm{c}$ & $0.00 \mathrm{e}$ \\
\hline U11 & 11.5 & $0 \mathrm{e}$ & $0 \mathrm{f}$ & $0.000 \mathrm{~d}$ & $0.000 \mathrm{f}$ & $0 \mathrm{~b}$ & $0.00 \mathrm{c}$ & $0.00 \mathrm{e}$ \\
\hline U12 & 8.8 & $0 \mathrm{e}$ & $0 \mathrm{f}$ & $0.000 \mathrm{~d}$ & $0.000 \mathrm{f}$ & $0 \mathrm{~b}$ & $0.00 \mathrm{c}$ & $0.00 \mathrm{e}$ \\
\hline \multicolumn{2}{|c|}{ CV $(\%)$} & 15.21 & 15.77 & 17.32 & 14.57 & 148.59 & 31.78 & 24.44 \\
\hline
\end{tabular}

${ }^{1}$ Means followed by the same letters, within each column, do not differ by Tukey test at $5 \%$ probability. 
Table 3. Results obtained for drying seeds from Lot 01, Treatment 04 - seedling emergence and emergence speed rate (ESR) at 90 and 135 days, first count of seedling emergence (FC), shoot length of seedling (SL) and dry mass of seedling (DM).

\begin{tabular}{|c|c|c|c|c|c|c|c|c|}
\hline \multirow{2}{*}{ Т 04} & \multirow{2}{*}{$\begin{array}{c}\text { Water } \\
\text { Content }(\%)\end{array}$} & \multicolumn{2}{|c|}{ Emergence (\%) } & \multicolumn{2}{|c|}{ ESR } & \multirow{2}{*}{$\begin{array}{l}\mathrm{FC} \\
(\%)\end{array}$} & \multirow{2}{*}{$\begin{array}{l}\mathrm{SL} \\
(\mathrm{cm})\end{array}$} & \multirow{2}{*}{$\begin{array}{l}\mathrm{DM} \\
(\mathrm{g})\end{array}$} \\
\hline & & 90 days & 135 days & 90 days & 135 days & & & \\
\hline U0 & 44.9 & $73 a b^{1}$ & $87 \mathrm{a}$ & $1.175 \mathrm{a}$ & $1.294 \mathrm{a}$ & $0 \mathrm{a}$ & $17.84 \mathrm{a}$ & $2.39 \mathrm{ab}$ \\
\hline U1 & 42.0 & $76 \mathrm{a}$ & $86 \mathrm{a}$ & $1.206 \mathrm{a}$ & $1.286 \mathrm{a}$ & $0 \mathrm{a}$ & $19.24 \mathrm{a}$ & $2.73 \mathrm{a}$ \\
\hline $\mathrm{U} 2$ & 39,0 & $50 \mathrm{~cd}$ & $77 \mathrm{ab}$ & $0.718 \mathrm{~b}$ & $0.946 \mathrm{~b}$ & $0 \mathrm{a}$ & $13.90 \mathrm{a}$ & $2.01 \mathrm{bc}$ \\
\hline U3 & 35.3 & $53 \mathrm{c}$ & $67 \mathrm{~b}$ & $0.742 \mathrm{~b}$ & $0.886 \mathrm{~b}$ & $0 \mathrm{a}$ & $16.66 \mathrm{a}$ & $1.79 \mathrm{c}$ \\
\hline U4 & 33.0 & $56 \mathrm{bc}$ & $64 \mathrm{~b}$ & $0.697 \mathrm{~b}$ & $0.806 \mathrm{~b}$ & $0 \mathrm{a}$ & $16.61 \mathrm{a}$ & $1.55 \mathrm{c}$ \\
\hline U5 & 29.7 & $33 \mathrm{de}$ & $40 \mathrm{c}$ & $0.362 \mathrm{c}$ & $0.491 \mathrm{c}$ & $0 \mathrm{a}$ & $16.06 \mathrm{a}$ & $0.93 \mathrm{~d}$ \\
\hline U6 & 25.8 & $16 \mathrm{ef}$ & $17 \mathrm{~d}$ & $0.204 \mathrm{~cd}$ & $0.225 \mathrm{~d}$ & $0 \mathrm{a}$ & $16.27 \mathrm{a}$ & $0.39 \mathrm{de}$ \\
\hline U7 & 22.4 & $5 \mathrm{f}$ & $5 \mathrm{de}$ & $0.049 \mathrm{~d}$ & $0.063 \mathrm{~d}$ & $0 \mathrm{a}$ & $13.21 \mathrm{a}$ & $0.12 \mathrm{e}$ \\
\hline U8 & 20.4 & $0 \mathrm{f}$ & $0 \mathrm{e}$ & $0.000 \mathrm{~d}$ & $0.000 \mathrm{~d}$ & $0 \mathrm{a}$ & $0.00 \mathrm{~b}$ & $0.00 \mathrm{e}$ \\
\hline U9 & 17.7 & $0 \mathrm{f}$ & $0 \mathrm{e}$ & $0.000 \mathrm{~d}$ & $0.000 \mathrm{~d}$ & $0 \mathrm{a}$ & $0.00 \mathrm{~b}$ & $0.00 \mathrm{e}$ \\
\hline U10 & 14.7 & $0 \mathrm{f}$ & $0 \mathrm{e}$ & $0.000 \mathrm{~d}$ & $0.000 \mathrm{~d}$ & $0 \mathrm{a}$ & $0.00 \mathrm{~b}$ & $0.00 \mathrm{e}$ \\
\hline U11 & 10.8 & $0 \mathrm{f}$ & $0 \mathrm{e}$ & $0.000 \mathrm{~d}$ & $0.000 \mathrm{~d}$ & $0 \mathrm{a}$ & $0.00 \mathrm{~b}$ & $0.00 \mathrm{e}$ \\
\hline U12 & 8.1 & $0 \mathrm{f}$ & $0 \mathrm{e}$ & $0.000 \mathrm{~d}$ & $0.000 \mathrm{~d}$ & $0 \mathrm{a}$ & $0.00 \mathrm{~b}$ & $0.00 \mathrm{e}$ \\
\hline \multicolumn{2}{|c|}{ CV $(\%)$} & 28.82 & 20.99 & 32.40 & 23.93 & - & 27.82 & 27.34 \\
\hline
\end{tabular}

${ }^{1}$ Means followed by the same letters, within each column, do not differ by Tukey test at $5 \%$ probability.

For Lot 02 seeds, there has been a significant reduction in percentage of seedling emergence at 90 and 135 days with water content $37.0 \%$ for treatment 04 (Table 4). For that same water content, a reduction in seedling dry mass was also found in relation to initial water content (Table 4). Seedling emergence was nulled from water content of $24.1 \%$ (Table 4 ). The speed rate of seedling emergence, as well as its first count, showed significant difference of $38.9 \%$ compared with initial water content. Seedling shoot length only showed the effects of drying for water content of $25.6 \%$. For treatment 01 , no seedling emergence was noted for any of the water contents analyzed, since prior immersion of fruit in water at $55^{\circ} \mathrm{C}$ for 20 minutes has caused the death of embryos.

Table 4. Results obtained for drying seeds from Lot 02, Treatment 04 - seedling emergence and emergence speed rate (ESR) at 90 and 135 days, first count of seedling emergence (FC), shoot length of seedling (SL) and dry mass of seedling (DM).

\begin{tabular}{|c|c|c|c|c|c|c|c|c|}
\hline \multirow{2}{*}{ Т 04} & \multirow{2}{*}{$\begin{array}{c}\text { Water } \\
\text { Content } \\
(\%)\end{array}$} & \multicolumn{2}{|c|}{ Emergence (\%) } & \multicolumn{2}{|c|}{ ESR } & \multirow{2}{*}{$\begin{array}{l}\mathrm{FC} \\
(\%)\end{array}$} & \multirow{2}{*}{$\begin{array}{c}\mathrm{SL} \\
(\mathrm{cm})\end{array}$} & \multirow{2}{*}{$\begin{array}{c}\mathrm{DM} \\
(\mathrm{g})\end{array}$} \\
\hline & & 90 days & 135 days & 90 days & 135 days & & & \\
\hline U0 & 45.9 & $88 a^{1}$ & $89 \mathrm{a}$ & $1.290 \mathrm{a}$ & $1.305 \mathrm{a}$ & $60 \mathrm{a}$ & $14.99 \mathrm{a}$ & $2.26 \mathrm{a}$ \\
\hline U1 & 38.9 & $70 \mathrm{ab}$ & $78 \mathrm{ab}$ & $0.923 \mathrm{~b}$ & $0.999 \mathrm{~b}$ & $0 \mathrm{~b}$ & $14.60 \mathrm{a}$ & $1.97 \mathrm{a}$ \\
\hline $\mathrm{U} 2$ & 37.0 & $52 \mathrm{~b}$ & $63 \mathrm{bc}$ & $0.651 \mathrm{c}$ & $0.759 \mathrm{bc}$ & $0 \mathrm{~b}$ & $14.03 \mathrm{ab}$ & $1.47 \mathrm{~b}$ \\
\hline U3 & 33.0 & $29 \mathrm{c}$ & $45 \mathrm{~cd}$ & $0.352 \mathrm{~d}$ & $0.512 \mathrm{~cd}$ & $0 \mathrm{~b}$ & $12.18 \mathrm{ab}$ & $0.93 \mathrm{c}$ \\
\hline U4 & 31.6 & $26 \mathrm{c}$ & $33 \mathrm{de}$ & $0.310 \mathrm{de}$ & $0.381 \mathrm{de}$ & $0 \mathrm{~b}$ & $11.06 \mathrm{ab}$ & $0.62 \mathrm{c}$ \\
\hline U5 & 27.1 & $0 \mathrm{~d}$ & $13 \mathrm{ef}$ & $0.000 \mathrm{f}$ & $0.132 \mathrm{ef}$ & $0 \mathrm{~b}$ & $8.24 \mathrm{abc}$ & $0.19 \mathrm{~d}$ \\
\hline U6 & 25.6 & $7 \mathrm{~d}$ & $9 \mathrm{f}$ & $0.103 \mathrm{ef}$ & $0.103 \mathrm{f}$ & $0 \mathrm{~b}$ & $7.25 \mathrm{bc}$ & $0.17 \mathrm{~d}$ \\
\hline U7 & 24.1 & $0 \mathrm{~d}$ & $1 \mathrm{f}$ & $0.000 \mathrm{f}$ & $0.010 \mathrm{f}$ & $0 \mathrm{~b}$ & $2.30 \mathrm{~cd}$ & $0.00 \mathrm{~d}$ \\
\hline U8 & 19.8 & $0 \mathrm{~d}$ & $0 \mathrm{f}$ & $0.000 \mathrm{f}$ & $0.000 \mathrm{f}$ & $0 \mathrm{~b}$ & $0 \mathrm{~d}$ & $0.00 \mathrm{~d}$ \\
\hline U9 & 14.6 & $0 \mathrm{~d}$ & $0 \mathrm{f}$ & $0.000 \mathrm{f}$ & $0.000 \mathrm{f}$ & $0 \mathrm{~b}$ & $0 \mathrm{~d}$ & $0.00 \mathrm{~d}$ \\
\hline U10 & 10.1 & $0 \mathrm{~d}$ & $0 \mathrm{f}$ & $0.000 \mathrm{f}$ & $0.000 \mathrm{f}$ & $0 \mathrm{~b}$ & $0 \mathrm{~d}$ & $0.00 \mathrm{~d}$ \\
\hline \multicolumn{2}{|c|}{$\mathrm{CV}(\%)$} & 34.38 & 32.97 & 32.49 & 30.43 & 24.35 & 41.79 & 28.79 \\
\hline
\end{tabular}

${ }^{1}$ Means followed by the same letters, within each column, do not differ by Tukey test at $5 \%$ probability.

The effects of dehydration on the physiological performance of Euterpe edulis seeds were also examined by Panza et al. (2007), Martins et al. (2009a, 2009b) and Roberto et al. (2011), indicating that the reduction in water content to values between $35-30 \%$ has hindered seed physiological performance with initial water content ranging from 50-45\%. These same authors have pointed out that water content from 18 to $29 \%$ is lethal for seeds of Euterpe edulis. 
Water loss in recalcitrant seeds may trigger several deteriorative processes, such as protein denaturation, changes in enzyme activity, and damage to the system of membranes, resulting in complete loss of seed feasibility (Nautiyal and Purohit, 1985; Wang et al., 2012). Furthermore, it may lead to a reduction in the speed of the metabolic processes, slowing the development of embryo during the pre-germination stage.

The physiological performance of seeds from fruit immersed in water at $40{ }^{\circ} \mathrm{C}$ for 20 minutes during the drying process was greater than that of seeds obtained from fruit that were not previously immersed in water. Besides the fact that the temperature of immersion has favored the protrusion of plant buds, as discussed above, the impact of the propellers in mechanical pulping has detached the fibrous portion of the mesocarp; while through manual pulping only the epicarp and the oleaginous portion of the mesocarp were removed, leaving the fibrous layer of the mesocarp adhered to the seed, making germination hard to occur and increasing the capacity of water retention when compared to the "clean" seeds. Thus, the mechanically pulped seeds have no physical barrier that hinders the germination process, leading to a faster germination, as evidenced by the first count of seedling emergence and speed of seedling emergence. Therefore, the mechanical pulping method may be considered advantageous for seedling emergence and for the subsequent seedling establishment in the soil.

\section{Conclusions}

Pulping methods where fruit are immersed in water at $40{ }^{\circ} \mathrm{C}$ for 20 minutes result in greater seed physiological performance when compared with methods that do not include prior fruit immersion in water.

Water temperature at $55{ }^{\circ} \mathrm{C}$ for fruit immersion for 20 minutes is harmful and causes seed death.

The method of pulp extraction, whether mechanical or manual, does not affect the physiological performance of seeds.

In mechanical pulping, no percentage reduction in seedling emergence is noted for water content of up to $33.3 \%$. Reduced water content to $16.1 \%$ causes seed death.

The dehydration of manually pulped seeds, of up to $39.0 \%$ water, does not affect seedling emergence. Water content lower than $25.6 \%$ causes seed death.

\section{References}

ANDRADE, A.C.S. The effect of moisture content and temperature on the longevity of heart of palm seeds (Euterpe edulis). Seed Science and Technology, v.29, p.171-182, 2001. http://www.academia.edu/881988/The effect_of_moisture_content_and_temperature_on_the_longevity_of_heart of_palm_Euterpe_edulis_seeds
BOVI, M.L.A.; CARDOSO, M. Seed germination of Euterpe edulis Mart. Bragantia, v.35, n.1, p.23-29, 1976. http://www.scielo.br/pdf/brag/v35n1/26.pdf

BOVI, M.L.A.; CARDOSO, M. Conservação de sementes de palmiteiro (Euterpe edulis Mart.). Bragantia, v.37, n.1, p.65-71, 1978.

BOVI, M.L.A.; GODOY-JUNIOR, G.; SAES, L.A. Pesquisas com os gêneros Euterpe e Bactris no Instituto Agronômico de Campinas. Agronômico, v.39, n.2, p.129-174, 1987.

BOVI, M.L.A. Pré-embebição em água e porcentagem e velocidade de emergência de sementes de palmiteiro. Bragantia, v.49, n.1, p.11-22, 1990. http://www.scielo.br/pdf/brag/v49n1/02.pdf

BRANCALION, P.H.S.; MARCOS-FILHO, J. Distribuição da germinação no tempo: causas e importância para a sobrevivência das plantas em ambientes naturais. Informativo ABRATES, v.18, p.11-17, 2008.

BRANCALION, P.H.S.; NOVEMBRE, A.D.L.C.; RODRIGUES, R.R. Seed development, yield and quality of two palm species growing in different tropical forest types in SE Brazil: implications for ecological restoration. Seed Science and Technology, v.39, n.2, p.412-424, 2011. http://www. ingentaconnect.com/content/ista/sst/2011/00000039/00000002/art00013

BRASIL. Ministério da Agricultura, Pecuária e Abastecimento. Regras para análise de sementes. Ministério da Agricultura, Pecuária e Abastecimento. Secretaria de Defesa Agropecuária. Brasília: MAPA/ACS, 2009. 395p http://www.agricultura.gov.br/arq_editor/file/laborat\%c3\%b3rio /sementes/ regras $\% 20$ para $\% 20$ analise $\% 20 \mathrm{de} \% 20$ sementes.pdf

CEMBRANELI, F.; FISH, T.V.; CARVALHO, C.P. Exploração sustentáve da palmeira Euterpe edulis Mart. no Bioma Mata Atlântica, Vale do ParaíbaSP. Revista Ceres, v.56, n.3, p.233-240, 2009. http://cncflora.jbrj.gov.br/ plataforma2/arquivos/biblio/4fc3c155aef18_V56N003P51809.pdf

COSTA, C.J.; MARCHI, E.C.S. Germinação de sementes de palmeiras com potencial para a produção de agroenergia. Planaltina-DF: Embrapa Cerrados. 2008. 35p

FANTINI, A.C.; GURIES, R.P. Forest structure and productivity of palmiteiro (Euterpe edulis Martius) in the Brazilian Mata Atlântica. Forest Ecology and Management, v.242, p.185-194, 2007. http://cmq.esalq.usp.br/wiki/lib/exe/ fetch.php?media=biometria:palmito:fantini-guries-2007.pdf

FERREIRA, S.A.N.; GENTIL, D.F.O. Extração, embebição e germinação de sementes de tucumã (Astrocaryum aculeatum). Acta Amazonica, v.36, n.2, p.141-146. 2006. http://www.scielo.br/pdf/\%0D/aa/v36n2/v36n2a02.pdf

FLEIG, F.D.; RIGO, S.M. Influência do tamanho dos frutos do palmiteiro Euterpe edulis Mart. na germinação das sementes e crescimento das mudas. Ciência Florestal, v.8, n.1, p.35-41, 1998.

GOMES, P.B.; VÁLIO, I.F.M.; MARTINS, F.R. Germination of Geonoma brevispatha (Arecaceae) in laboratory and its relation to the palm spatial distribution in a swamp. Aquatic Botany, v.85, p.16-20, 2006. http://www. sciencedirect.com/science/article/pii/S0304377006000155

GOUDEL, F.; SHIBATA, M.; COELHO, C.M.M.; MILLER, P.R.M. Fruit biometry and seed germination of Syagrus romanzoffiana (Cham.) Glassm. Acta Botanica Brasilica, v.27, n.1, p.147-154, 2013. http://www.scielo.br/ pdf/abb/v27n1/v27n1a15.pdf

IBGE. Instituto Brasileiro de Geografia e Estatística. Produção da Extração Vegetal e da Silvicultura, v.26, 2011. Acessed on Apr. 15 ${ }^{\text {th }}$. 2013. ftp://ftp. ibge.gov.br/Producao_Agricola/Producao__da_Extracao_Vegetal_e_da_ Silvicultura \%5Banual\%5D/2011/pevs2011.pdf. 
MAGUIRE, J.D. Speed of germination: aid in selection and evaluation for seedling emergence and vigor. Crop Science, v.2, n.2, p.176-177, 1962.

MARTINS, C.C.; BOVI, M.L.A.; NAKAGAWA, J.; GODOY JÚNIOR, G. Temporary storage of jussara palm seeds: effects of time, temperature and pulp on germination and vigor. Horticultura Brasileira, v.22, n.2, p.271-276, 2004. http://www.scielo.br/pdf/hb/v22n2/21029.pdf

MARTINS, C.C.; BOVI, M.L.A.; NAKAGAWA, J.; MACHADO, C.G. Secagem e armazenamento de sementes de juçara. Revista Árvore, v.33, p.635-642, 2009a. http://www.scielo.br/pdf/rarv/v33n4/v33n4a06.pdf

MARTINS, C.C.; MACHADO, C.G.; NAKAGAWA, J.; OLIVEIRA, S.S.C. Tamanho e secagem de sementes de palmeira Jussara sobre a germinação e o vigor. Revista Caatinga, v.22, p.117-120, 2009b. http://periodicos.ufersa. edu.br/revistas/index.php/sistema/article/view/1132/584

MARTINS, C.C.; NAKAGAWA, J.; BOVI, M.L.A. Desiccation tolerance of four seed lots from Euterpe edulis Mart. Seed Science and Technology, v.28, p.101-113, 2000

MYINT, T.; CHANPRASERT, W.; SRIKUL, S. Germination of seed of oil palm (Elaeis guianeensis Jacq.) as affected by different mechanical scarification methods. Seed Science and Technology, v.38, n.3, p.635-645, 2010. http://www. ingentaconnect.com/content/ ista/sst/2010/00000038/00000003/art00011

NAUTIYAL, A.R.; PUROHIT, A.N. Seed viability in sal. II. Physiological and biochemical aspects of ageing in seeds of Shorea robusta. Seed Science and Technology, v.13, n.1, p.69-76, 1985.

PANZA, V.; LÁINEZ, V.; MALDONADO, S. Seed structure and histochemistry in the palm Euterpe edulis. Botanical Journal of the Linnean Society, v.145, n.4, p.445-453, 2004. http://onlinelibrary.wiley.com/ doi/10.1111/j.1095-8339.2004.00293.x/pdf

PANZA, V.; LÁINEZ, V.; MALDONADO, S.; MARODER, H.L. Effects of desiccation on Euterpe edulis Martius seeds. Biocell, v.31, n.3, p.383-390, 2007. http://www.scielo.org.ar/ pdf/biocell/v31n3/v31n3a04.pdf
PIZO, M.A.; ALLMEN VON, C.; MORELLATO, L.P.C. Seed size variation in the palm Euterpe edulis and the effects of seed predators on germination and seedling survival. Acta Oecologica, v.29, p.311-315, 2006. http://www. sciencedirect.com/science/article/pii/S1146609X05001414

QUEIROZ, M.H.; CAVALCANTE, M.D.T.H. Efeito do dessecamento das sementes de palmiteiro na germinação e no armazenamento. Revista Brasileira de Sementes, v.8, n.3, p.121-125. 1986.

REIS, A.; SILVEIRA PAULILO, M.T.; NAKAZONO, E.M.; VENTURI, S. Effect of different level of desiccation in the seed germination of Euterpe edulis Martius - Arecaceae. Insula, v.28, p.31-42, 1999

ROBERTO, G.G.; HABERMANN, G. Morphological and physiological responses of recalcitrant Euterpe edulis seeds to light, temperature and gibberellins. Seed Science and Technology, v.38, p.367-378, 2010. http://www. ingentaconnect.com/content/ista/sst/2010/00000038/00000002/art00010

ROBERTO, G.G.; COAN, A.I.; HABERMANN, G. Water content and GA H $_{3}$ induced embryonic cell expansion explain Euterpe edulis seed germination, rather than seed reserve mobilization. Seed Science and Technology, v.39, n.3, p.559-571, 2011. http://www.ingentaconnect.com/content/ista sst/2011/00000039/00000003/art00003

SMITH, S.L.; SHER, A.A.; GRANT III, T. Genetic diversity in restoration materials and the impacts of seed collection in Colorado's restoration plant production industry. Restoration Ecology, v.15, n.3, p.369-374, 2007. http:// onlinelibrary.wiley.com/doi/10.1111/j.1526100X.2007.00231 .x/pdf

WANG, W.Q.; CHENG, H.Y.; SONG, S.Q. The role of recovery of mitochondrial structure and function in desiccation tolerance of pea seeds. Physiologia Plantarum, v.144, p.20-34, 2012. http://sourcedb.ib.cas.cn/cn/ ibthesis/201202/P020120216528870574542.pdf

WOLKERS, W.F.; ALBERDA, M.; KOORNNEEF, M.; LÉONKLOOSTERZIEL, K.M.; HOEKSTRA, F.A. Properties of proteins and the glassy matrix in maturation defective mutant seeds of Arabdopsis thaliana. The Plant Journal, v.16, n.2, p.133-143. 1998. 


\section{ERRATUM}

The Figure 1 of the article "Fruit processing and the physiological quality of Euterpe edulis Martius seeds", published on Journal of Seed Science, v. 36, n. 2, p. 134 - 142, 2014, is not correct. The corrected Figure can be find below. The authors regret the error.

http://dx.doi.org/10.1590/2317-1545v32n2847
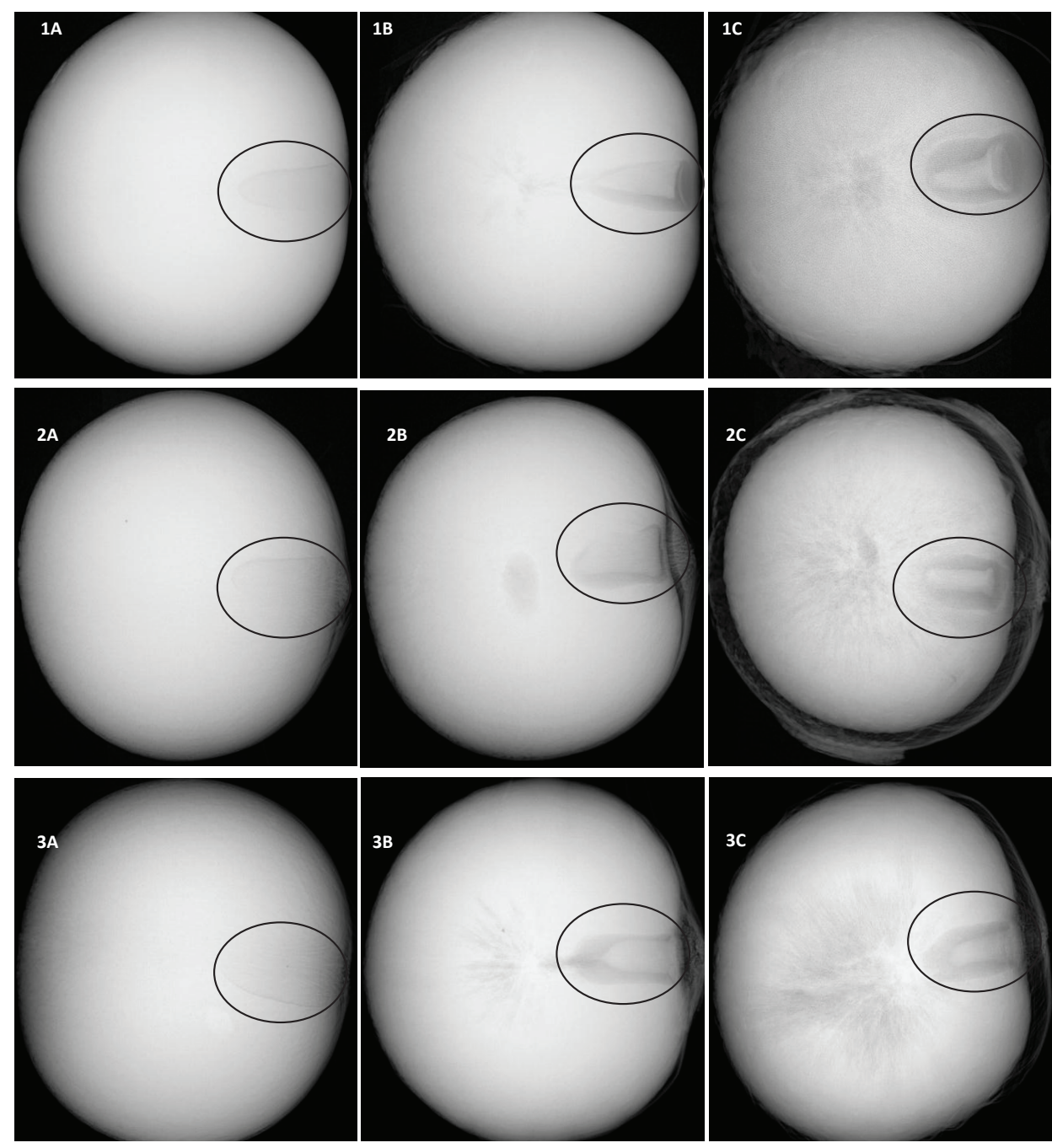

Figure 1. Representative image of the reduction of the volume occupied by the embryo within the embryo cavity throughout the drying process. 1 - Radiographic images that refer to treatment 01 , Lot $01.1 \mathrm{~A}$ - initial water content of $44.9 \%$; $1 \mathrm{~B}$ - critical water content of 33.3\%; 1C - lethal water content of 16.1\%. 2 - Radiographic images that refer to treatment 04, Lot 01. 2A - initial water content of $44.9 \%$; $2 \mathrm{~B}$ - critical water content of $39.0 \%$; $2 \mathrm{C}$ - lethal water content of $20.4 \% .3$ - Radiographic images that refer to treatment 04 , Lot $02.3 \mathrm{~A}$ - initial water content of $45.9 \%$; $3 \mathrm{~B}$ - critical water content of $37.0 \%$; $3 \mathrm{C}$ - lethal water content of $27.1 \%$. Embryo is highlighted. 


\section{ERRATA}

A Figura 1 do artigo "Fruit processing and the physiological quality of Euterpe edulis Martius seeds", publicado no Journal of Seed Science, v. 36, n. 2, p. 134 - 142, 2014, continha erros na formatação que haviam passado despercebidos pelos autores. A figura com a formatação correta segue abaixo.

http://dx.doi.org/10.1590/2317-1545v32n2847
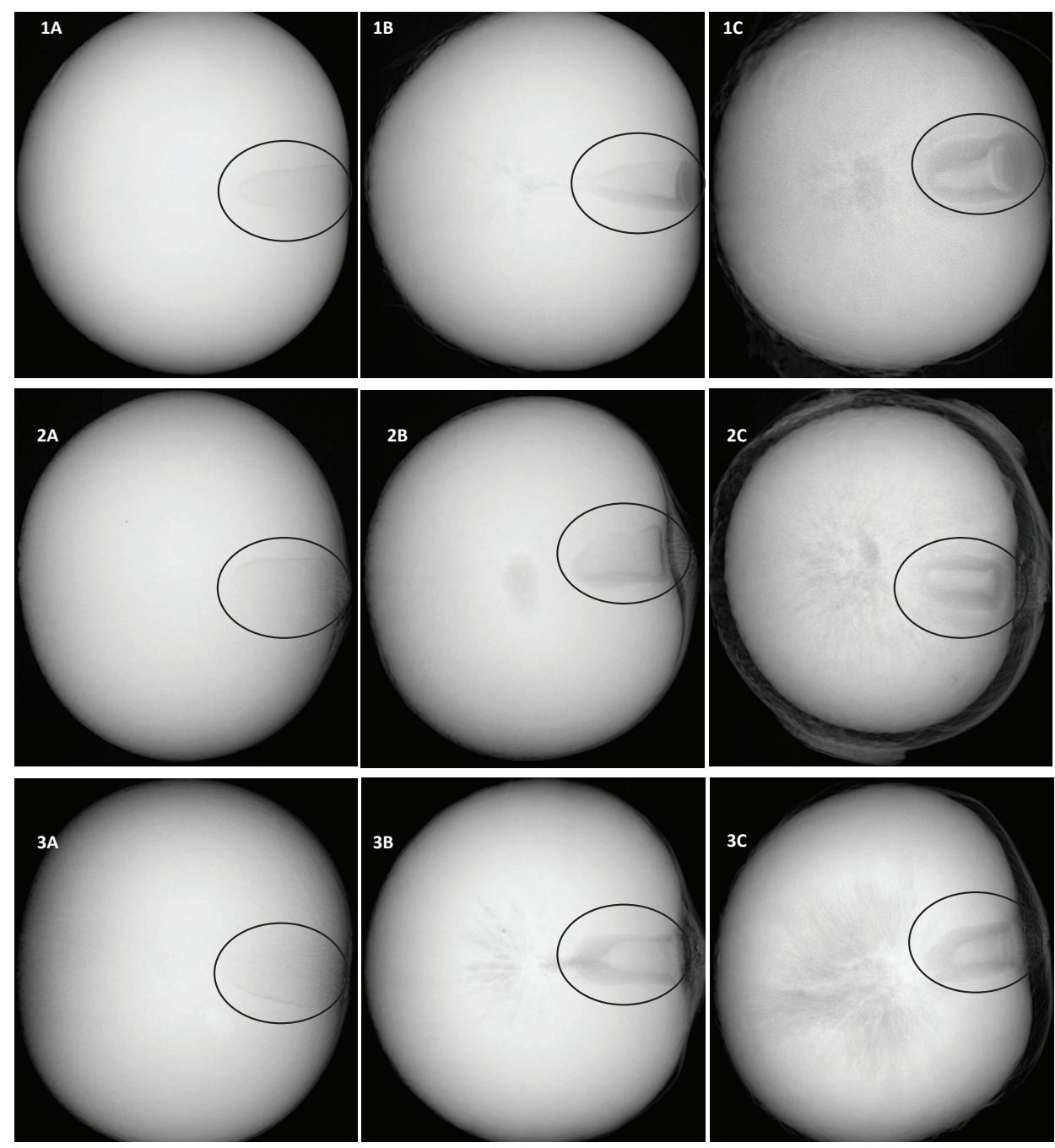

Figura 1. Imagem representativa da redução do volume ocupado pelo embrião dentro da cavidade embrionário durante a evolução do processo de secagem. 1- Imagens radiográficas referentes ao tratamento 01, lote 01. 1A - teor de água inicial de 44,9\%; 1B - teor de água crítico de 33,3\%; 1C - teor de água letal de 16,1\%. 2- Imagens radiográficas referentes ao tratamento 04 , lote $01.2 \mathrm{~A}$ - teor de água inicial de 44,9\%; $2 \mathrm{~B}$ - teor de água crítico de 39,0\%; 2C - teor de água letal de 20,4\%. 3- Imagens radiográficas referentes ao tratamento 04, lote 02. 3A - teor de água inicial de $45,9 \%$; $3 \mathrm{~B}$ - teor de água crítico de 37,0\%; 3C - teor de água letal de 27,1\%. Em destaque o embrião. 